\title{
The Use Of Spirulina In The Development Of High- Protein Bioindustry In Order To Optimize Public Health
}

\author{
$1^{\text {st }}$ Faidliyah Nilna Minah ${ }^{1}, 2^{\text {nd }}$ Siswi Astuti ${ }^{2}, 3^{\text {rd }}$ M. Fourry Handoko ${ }^{3}$ \\ \{nilnaminah@yahoo.com ${ }^{1\}}$ \\ Chemical Engineering Department, National Institute of Technology (ITN) Malang ${ }^{1}$, Chemical \\ Engineering Department, National Institute of Technology (ITN) Malang ${ }^{2}$, Chemical Engineering \\ Department, National Institute of Technology (ITN) Malang ${ }^{3}$
}

\begin{abstract}
The potential of spirulina as a healthy biomass for food or skin healthcare products such as soaps and facial masks need to be maximized. This is because the proteins and vitamins that are required by human can be found within spirulina, which is why it is called "Superfood". The cultivation and processing of spirulina in Indonesia is not often found, thus, the demands for spirulina are fulfilled through importing from China and US. Therefore, this program aims to cultivate, as well as to process spirulina into food and skin healthcare products. Cultivation products are made into a form of spirulina powder which is then used as an additional ingredients for shower soap products, facial masks, shampoos, fish/livestock foods, snacks or cookies, ice creams, and pastries. The purpose of the use of spirulina is so that a high-protein bioindustry can be developed within the campus, making it one of its source of income as well as that it would escalate campus' business and competitive quality on the basis of lecturers' and scholars' intellectual product; healthy foods and natural skin healthcare products. Spirulina products' marketing and promotion for this stage are limited to campus environment, campus cooperatives, and online media. Result shows that items sold within the first five months are 90 bars of soap, 1 bottle of shampoo, 13 bottles of mask, 31 packs of cookies, 133 units of ice cream, and 1350 pieces of pastries. The availability of cultivated spirulina powder is relatively small, which is 533,3 grams. Hence, there needs to be an expansion of lands for cultivation as well as the control for temperature, alkalinity, and light condition so that spirulina's productivity increases, along with the evaluation for product prices that are less attractive to the public.
\end{abstract}

Keywords: spirulina, cultivation, masker, soap, shampoo, snacks, productivity

\section{Introduction}

Human desire to become healthy is one of the main factors that comes to play in life. Primary food intake which has balanced nutrition, healthy complementary foods, and physical health are the main factors for life sustainability. Spirulina is one of marine biota from cyanobacteria group named arthospira cyanobacteria or Arthrospira (Spirulina) platensis which have trade name of Spirulina is full of health benefirs to human as well as being known as superfood for having high nutritional value, high on vitamins, essential fatty acids, and 
pigments which makes it a practical food for astronauts that go to moon. Spirulina can grow well at limited indoor or outdoor area subtropic or tropic, warm, alkali condition [1].

Daily spirulina growth acceleration go around $25 \%$ of its original weight [2]. By consuming 30 grams of spirulina per day, the necessary amount of mineral and vitamin such as protein, iron, calcium, vitamin B12, antioxidants, and anti-allergy can be sufficed. Spirulina is spiral-shaped, but under various environmental conditions such as temperature, physical environment, and the condition of growth solution affects helix structure. Spirulina platensis has a blue pigment known as Phycocyanobilin and this type can inhibit HIV-1 [3].

The biggest spirulina cultivation in Indonesia is currently undergone by PT Neoalga Indonesia Makmur Sukoharjo, Central Java. Its yields are sold in the form of capsules for supplements, while the remaining spirulina needs are still imported from China and US. Which is why, there needs to be an effort to increase the production of spirulina powder and the development of spirulina-processing industries needed by public; shower soaps, facial masks, shampoos, and snacks. The cultivation of micro algaes of Chlorella Sp. in photobioreactor as well as the study of its kinetics and calorie value using thermogravimetry analyzer shows a excellent result with high calorie value [4]. While the marine algae cultivation of green macroalgae Caulerpa taxifolia carried out by Poespowati [5] shows a significant growth result. In order for spirulina to grow, the temperature must be maintained with a minimum of $15^{\circ} \mathrm{C}$ and maximum of $38-40^{\circ} \mathrm{C}$ [6]. Despite having different algae media, but the obstacles and conveniences can be used as references in the proposed activity plan. Spirulina cultivation is suitable to be developed as an alternative to public who are interested in business requiring relatively small capital without needing a large land. Ponds with a size of $20 \mathrm{~m}^{2}$ can produce 200 grams of spirulina per day, having enough additional nutritional intake for 150 children [7]. As for adults, they are only required to consume 5-10 grams per day of dry spirulina [2].

Spirulina has several benefits due to its high protein content [8][9] which is $63-68 \%, 18$ $20 \%$ carbohydrates, $2-3 \%$ fat [9]. Other fact about spirulina is that its protein content is 3 (three) times as many as meat, with iron levels 50 (fifty) times as many as those is spinach, vitamin A 15 (fifteen) times as many as carrot, as well as containing high levels of vitamin B12, anti-allergy, antioxidants, vitamin $\mathrm{K}$, chlorophyll, phycocyanin, calcium, and magnesium [2], so that there is a possibility of it being used as an alternative food for people having autism.

Results from several reference studies stated that spirulina can cure various diseases like cancer, anemia, lowering cholesterol level, and it can be used as the raw material to make cosmetics and medicines [10][2][11].

The main activity that will be done is to cultivate Spirulina Platensis which will then be harvested, dried, and made into ready-to-use powder that can be directly mixed with breads or drinks and used as other food additives. Bioindustries that focuses on Spirulina Platensis will be developed from the beginning, i.e. the cultivation process itself, until the end which consists of processing the harvests into 4 variants of spirulina-based products.

If the daily spirulina consumption of children and adults is 5,6 gram then the total daily spirulina need is $4.938 .046,4$ gram. If $1 \%$ of Malang City population are willing to consume spirulina, then the proposed spirulina product of 400 grams per day is still not enough, in the event that public's interest toward it has been awakened. The type of established business is spirulina cultivation and green-technology-based spirulina product diversification to support healthy living. 


\section{Methods of implementation}

Activities that will be performed in this program is the procurement of raw materials, procurement of auxiliary materials for processed spirulina products, procurement of tools and equipments, production of processed spirulina, product analysis, and product marketing. The required raw materials during cultivation are spirulina seedlings or strains. Raw material quality is an important term in order for the cultivation process to occur perfectly. The process of cultivating spirulina requires cultivating place, secchidisk to observe spirulina density, spectrophotometer, $\mathrm{pH}$ meter to measure water alkalinity, refractometer to measure water salinity, lux meter to measure the intensity of light, and thermo controller to adjust the growth media temperature. During the production of processed spirulina, the necessary equipments are cupboard to keep the products, freezer, refrigerator, milling machine, packaging machine, oven, scales, grinder machine, stove, mixer, sealer, and ice cream machine.

\section{Result and discussion}

This research results Spirulina in the form of 533,3 grams of powder in the span of 8 months; a result far from what was originally proposed. This is due to various adjustments from the initial condition which required lengthy duration. Differences in temperature, alkalinity, air circulation, and light greatly affect spirulina growth. Which is exactly why, a different test located outdoor with a different condition is required.

Almost all processed spirulina products are sold with the exception of shampoos and livestock food which shows lack of interests. An interview result with product user shows that the product price are not expensive, thus people with moderate-to-low income are able to buy the products. Processed spirulina products can be seen on the table 1.

Table 1. Processed spirulina products sold from march - august 2018 


\begin{tabular}{|c|c|c|c|c|c|c|c|c|}
\hline & Product Type & March & April & May & Juse & July & August & Total \\
\hline 1. & Shower Soap & 34 & 3 & 12 & 16 & 13 & 10 & 90 \\
\hline 2. & Shampoo & 1 & . & $\cdot$ & $\cdot$ & . & - & 1 \\
\hline 3. & Facial Mask & 4 & 2 & 2 & 3 & 2 & - & 13 \\
\hline 4. & Cookie & 10 & 10 & $\cdot$ & 11 & . & $\cdot$ & 31 \\
\hline 5. & Ice Cream & 30 & 84 & 49 & $\cdot$ & - & $\cdot$ & 133 \\
\hline 6. & Pastry & . & 100 & 125 & $\cdot$ & 750 & 375 & 1350 \\
\hline
\end{tabular}

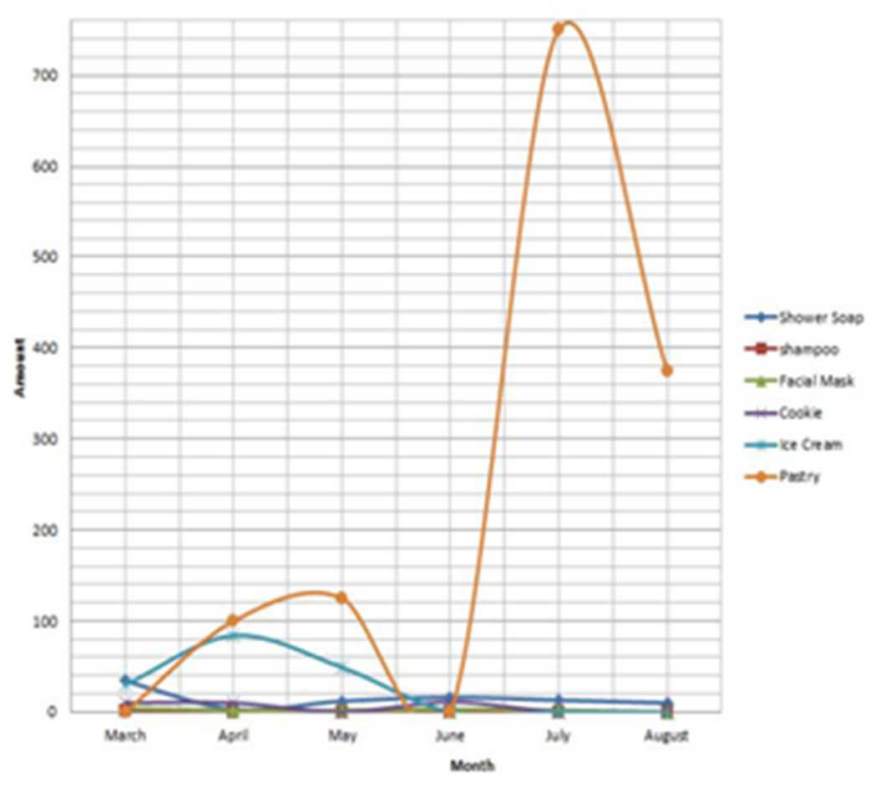

Figure 1. Graph of Processed Spirulina Products Sold from March-August 2018

Figure 1 shows that pastries can be further developed by expanding marketing area and marketing media, especially promotional media. Public interest towards pastries are relatively larger than the rest, this is most likely due to its cheap price without compromising its nutritional value and its attractive appearance in comparison with similar pastries with conventional looks.

In order for sales to additionally increase, a better promotion with larger promotional area is required. Only then, pastry marketing will not only limited through booking, but also open up opportunities for collaboration with elementary and middle school canteens.

The second highest sale belongs to spirulina ice cream. Similar to pastries, marketing are ought to be expanded not only within campus, but hopefully there will be a cooperation between elementary and middle school canteens.

Shower soaps which can also be used as facial soap is proven to be suitable for use because it can moisturize the skin, though its quality and quantity can be improved for future productions. Analysis result indicates that its water content is $16,80 \%$ with its free fatty acid 
content is 3,56\%. As a result, longer curing duration is needed in order to it to conform to SNI 06-3532-1994 standard of maximum 15\% water content and 2,5-7,5\% free fatty acid content.

Facial mask product are, in fact, liked by most of the consumer after trying them on but due to its high price, a single product is often bought by multiple consumer (shared expense). Which is why a packaging model with less, but well-designed capsule is needed to produce so that it is not easily damaged. Unfortunately, cookies are only liked by certain people, so it is advised to be replaced with a cheaper snack alternative. The first five month are used to explore processed spirulina products in the market to find out the less-preferred products that will be replaced with another product.

\section{Conclusion}

Overally, processed of knowledge transfer regarding spirulina as a knowledge and products can become a source of income and knowledge improvement (since knowledge and technology transfer could improve the knowledge and the capability of its receiver) $[12][13][14][15][16]$, on the basis of lecturer's and university students' intellectual product which will be able to motivate other students to become an entrepreneur. In order for spirulina products to reach the desired target, accurate promotional media and marketing, product price evaluation, as well as consumer evaluation is needed, bearing in mind that general public is not yet aware that spirulina can become a super food.

Acknowledgements. This paper in conjuction with the 9th International Conference On Green Technology (ICGT) 2018.

\section{References}

[1] Vardaka E, Kormas KA, Katsiapi M, Genitsaris S, Moustaka-Gouni M. Molecular diversity of bacteria in commercially available "Spirulina" food supplements (2016). PeerJ 4:e1610 https://doi.org/10.7717/peerj.1610

[2] Keren, D. 2014. Be the Medicine, a Guide to Growing Organic Spirulina at Home. www.groworganicspirulina.com. Diakses 20 April 2017.

[3] A.K. Shabana, S.M. Arabi, "Spirulina, an Overview", International Journal of Pharmacy and Pharmaceutical Sciences, vol 4 issue 3, 2012.

[4] Poespowati, T., Moghtaderi, B. and Ismay, M. 2010. Kinetics and Pyrolysis Study of Chlorella Sp. Using Thermogravimetric Analiser, The third International Symposium on Energy from Biomass and Waste, Cini Foundation, Venice, Italy, 8 - 11 November 2010.

[5] Poespowati, T., Jimmy, Noertjahjono, S. Cultivation of Caulerpa Taxifolia as Feedstock of Bioenergy. The International Institute for Science, Technology and Education, Vol. 3, No. 1, 2013.

[6] Christwardana, M.M.A.Nur, Hadiyanto, Spirulina Plantesis: Potensinya sebagai Bahan Pangan Fungsional, Jurnal Aplikasi Teknologi Pangan, Vol 2 No.1, 2013.

[7] Santoso, W. dan Limantara, L. Kultivasi Spirulina. Majalah Biologi Populer, Oktober 2007. Vol. 1, No. 2 2007.

[8] Amanatin, D.R. dan Nurhidayati, T. Pengaruh Kombinasi Konsentrasi Media Ekstrak Tauge (MET) dengan Pupuk Urea terhadap Kadar Protein Spirulina sp. Jurnal Sains dan Seni Pomits Vol. 2, No. 22013.

[9] Hariyati, R. Pertumbuhan dan Biomassa Spirulina sp dalam Skala Laboratoris. BIOMA, Vol. 10, No. 1 2008 
[10] Morais, M.G. et al. Pilot scale semicontinuous production of Spirulina biomass in Southern Brazil. Aquaculture 294, 60-64 2009.

[11] Kumari, A. et al. 2014. Carbon dioxide assisted Spirulina platensis cultivation using NPK-10:26:26 complex fertilizer in sintered disk chromatographic glass bubble column. Journal of CO2 Utilization. http://dx.doi.org/10.1016/j/jou.2014.07.001

[12] F. Handoko, S. Alan, and C., Burvill, "The Role of Government, Universities, and Business in Advancing Technology for SMEs' innovation. Journal of Chinese Economic and Business Studies. Vol 12, No. 2. pp. 171, 2014

[13] Handoko, F., Nursanti,E., Harmanto, D and Sutriyono, Technology Transfer For Metal Based SMEs In Central Java, Indonesia. ARPN Journal of Engineering and Applied Sciences, Vol.11, No. 82016.

[14] Handoko, F, Constructing Knowledge and Technology Transfer Model for SMEs Technology Development in Emerging Economies. International Journal of Pedagogy and Teacher Education. Vol 1, No. 2. pp. 932017.

[15] Handoko, F., Smith, A., Indriani, S. Technology Transfer for Metal Based SMEs in Central Java Indonesia. International Journal of Engineering and Management, [S.1.], v. 1, n. 1, p. 35-41 2017.

[16] Handoko, F., Nursanti, E., Gatot, Tjahjadi, M.E., Hutabarat, J., Mulyadi, L., and Kustamar. 2018. Green Industrial System in Indonesia, MATEC Web Conf., 164 (2018) 01010, DOI: https://doi.org/10.1051/matecconf/201816401010 